\title{
МОДЕЛЬ ФАКТОРІВ НЕСПРИЯТЛИВОГО ВПЛИВУ НА ОТОЧУЮЧЕ СЕРЕДОВИЩЕ
}

() Т. В. Олянишен, к.т.н., асистент, В. М. Сторожук, к.т.н., доцент, Національний лісотехнічний університет України; І. В. Піх, К.т.н., доцент, О. В. Мельников, К.т.н., директор видавництва УАД, УАД, Львів, Україна

Разработана модель иерархии факторов неблагоприятного влияния на окружающую среду, которая кроме упорядочения по важности влияния сделала возможным дальнейшее деление на зависимые (внутренние) компоненты для выявления степени ослабления или усиления действия вызывающего фактора.

The model of hierarchy of factors of adverse influence on environment which except streamlining on importance of influence has made possible the further division into dependent (internal) components for revealing of degree of easing or strengthening of action of the causing factor is developed.

\section{Постановка проблеми}

Підприємства, в результаті виробничо-господарської діяльності, впливають на атмосферне повітря, відбувається забруднення атмосфери - змінення складу і властивостей атмосферного повітря в результаті надходження або утворення в ньому фізичних, біологічних факторів і (або) хімічних сполук, що можуть несприятливо впливати на здоров'я людини та стан навколишнього природного середовища. Ступінь несприятливого впливу на атмосферу залежить від багатьох факторів, зокрема від визначених авторами раніше [1-13]. Для забезпечення екологічної безпеки, створення сприятливого середовища життєдіяльності, запобігання шкідливому впливу атмосферного повітря на здоров'я людей та навколишнє природне середовище, відповідно до законодавства України і досягнутих міжнародних домовленостей, чинних на території України [14], здійснюється регулювання викидів найбільш поширених і небезпечних забруднюючих речовин, перелік яких встановлюється Кабінетом Міністрів України [15].

Сутність впливу визначених факторів [12] на оточуюче середовище носить багато у чому описовий характер, незважаючи на існуючий аналіз причин і наслідків [1, 9, 10, 13]. Найчастіше можна встановити ступінь впливу на оточуюче середовище кожного фактора окремо, без урахування побічної дії інших факторів. Спроба узагальнити ці дані поки що формально фіксує результат, нехай і підтверджений фактичним матеріалом. 
Цікавими, на наш погляд, та важливими з точки зору ефективності прогнозування ситуації могли б стати дослідження, яким притаманні методи попереднього визначення впливу на оточуюче середовище множини обраних факторів.

\section{Мета роботи}

Розроблення моделі ієрархії факторів, яка, крім упорядкування за важливістю впливу на процес, уможливила б подальший поділ на підпорядковані (внутрішні) компоненти для виявлення ступеня послаблення чи посилення дії спричиняючого фактора.

\section{Результати проведених досліджень}

Постановка та розв'язання вищезазначених задач вимагають виявлення максимально повної множини узагальнених факторів, встановлення експертних оцінок взаємозв'язків і взаємовпливів у вибраному інформаційному середовищі [16].
Нехай сукупність таких факторів становить деяку множину $Z=\left\{z_{1}, z_{2}, \ldots, z_{n}\right\}$. 3 цієї сукупності виберемо підмножину $\mathrm{Z}_{1} \in \mathrm{Z}$ найсуттєвіших факторів. Для наочності математичне позначення фактора доповнимо його мнемонічною назвою (табл. 1).

Підмножину факторів $Z_{1}$ та можливі взаємозв'язки між ними подамо у вигляді орієнтованого графа (рис. 1), у вершинах якого розміщено елементи підмножини $Z_{1}$, дуги 3'єднують суміжні пари вершин $\left(z_{\mathrm{i}}, \mathrm{z}_{\mathrm{j}}\right)$, для котрих визначено зв'язок. Він вказує на певну залежність одного фактора від іншого. Наприклад, автори вважали що за сьогоднішнього розвитку виробництва та жорстких вимог до забруднення навколишнього середовища ступень впровадження системи охорони навколишнього природного середовища (COHC) багато у чому визначає застосовувані технології (ТЕХH) та використовувані матеріали та речовини (МАТ).

Таблиця 1

Мнемонічна назва

\begin{tabular}{|c|c|c|}
\hline $\begin{array}{l}\text { Математичне } \\
\text { позначення }\end{array}$ & Назва & $\begin{array}{l}\text { Мнемонічна } \\
\text { назва }\end{array}$ \\
\hline $\mathrm{Z}_{1}$ & вид виробництва & BB \\
\hline $\mathrm{Z}_{2}$ & застосовувані технології & TEXH \\
\hline $\mathrm{Z}_{3}$ & використовувані матеріали та речовини & MAT \\
\hline$Z_{4}$ & $\begin{array}{l}\text { герметичність устаткування та технологічних } \\
\text { установок }\end{array}$ & ГЕРМ \\
\hline$Z_{5}$ & $\begin{array}{l}\text { ефективність пило- та газоочисного устатку- } \\
\text { вання }\end{array}$ & EФ \\
\hline $\mathrm{Z}_{6}$ & рівень культури виробництва & KB \\
\hline $\mathrm{Z}_{7}$ & $\begin{array}{l}\text { ступінь впровадження системи охорони на- } \\
\text { вколишнього природного середовища }\end{array}$ & $\mathrm{COHC}$ \\
\hline
\end{tabular}




\section{ТЕХНОЛОГІЧН І ПРО ЦЕ С И}

На основі вищеподаного графа будуємо бінарну матрицю залежності А для множини вершин $Z_{1}$ наступним чином [16]:

$$
a_{i j}=\left\{\begin{array}{l}
1, \text { якщо критерій(вершина) і залежить від критерію (вершини) j; } \\
0, \text { якщо критерій (вершина) і не залежить від критерію (вершини) j. }
\end{array}\right.
$$

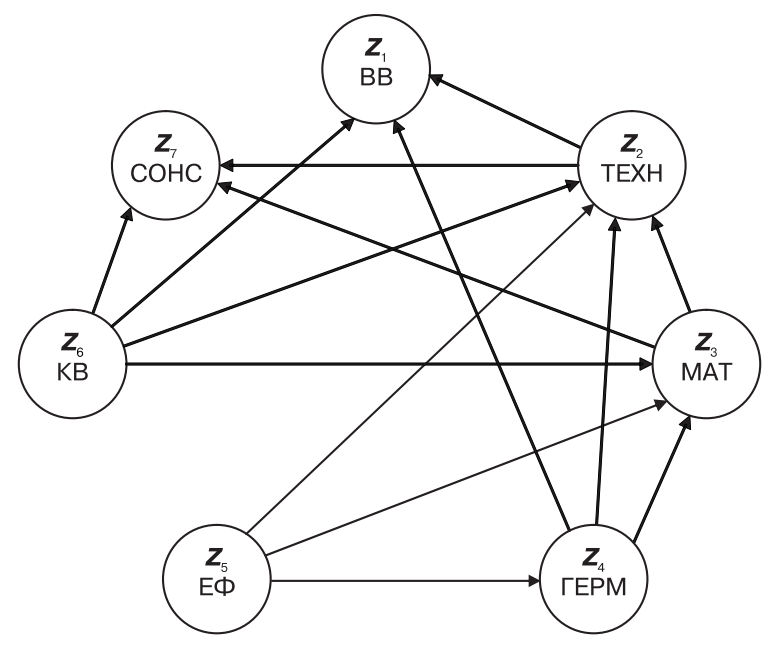

Рис. 1. Граф взаємозв'язків і взаємних впливів факторів несприятливого впливу на оточуюче середовище

Для зручності матрицю А розмірності $7 \times 7$ елементів помістимо в таблицю, додавши до неї інформаційний рядок і стовпець з назвами факторів.

\begin{tabular}{|c|c|c|c|c|c|c|c|c|}
\hline & BB & 0 & 0 & 0 & 0 & 0 & 0 & 0 \\
\hline & TEXH & 1 & 0 & 0 & 0 & 0 & 0 & 1 \\
\hline & MAT & 0 & 1 & 0 & 0 & 0 & 0 & 1 \\
\hline & IEPM & 1 & 1 & 1 & 0 & 0 & 0 & 0 \\
\hline & EФ & 0 & 1 & 1 & 1 & 0 & 0 & 0 \\
\hline & KB & 1 & 1 & 1 & 0 & 0 & 0 & 1 \\
\hline & $\mathrm{COHC}$ & 0 & 0 & 0 & 0 & 0 & 0 & 0 \\
\hline
\end{tabular}

Використовуючи матрицю А, будуємо матрицю досяжності таким чином. Формуємо бінарну матрицю (I+A), де I - одинична матриця. У результаті матриця досяжності повинна задовольняти умову

$$
(I+A)^{k-1} \leq(I+A)^{k}=(I+A)^{k+1}
$$

Практично іï̈ побудова зводиться до заповнення таблиці, подібної до наведеної вище, бінарні елементи якої визначаються за таким правилом:

$$
\mathrm{b}_{\mathrm{ij}}=\left\{\begin{array}{l}
1, \text { якщо з і можна попасти в j } \\
0, \text { в іншому випадку. }
\end{array}\right.
$$

\begin{tabular}{|c|c|c|c|c|c|c|c|}
\hline & BB & TEXH & MAT & ГЕРМ & $E \Phi$ & KB & $\mathrm{COHC}$ \\
\hline BB & 1 & 0 & 0 & 0 & 0 & 0 & 0 \\
\hline TEXH & 1 & 1 & 0 & 0 & 0 & 0 & 1 \\
\hline MAT & 1 & 1 & 1 & 0 & 0 & 0 & 1 \\
\hline IEPM & 1 & 1 & 1 & 1 & 0 & 0 & 1 \\
\hline $\mathrm{E \Phi}$ & 1 & 1 & 1 & 1 & 1 & 0 & 1 \\
\hline KB & 1 & 1 & 1 & 0 & 0 & 1 & 1 \\
\hline $\mathrm{COHC}$ & 0 & 0 & 0 & 0 & 0 & 0 & 1 \\
\hline
\end{tabular}

$\begin{array}{lllllll}1 & 2 & 3 & 4 & 5 & 6 & 7\end{array}$ 
Вершина $z_{j}$ досягається 3 вершини $z_{i}$, якщо в графi (рис. 1) існує шлях, який приводить з вершини $z_{\mathrm{i}}$ до вершини $\mathrm{z}_{\mathrm{j}}$. Така вершина називається досяжною. Позначимо підмножину подібних вершин через $\mathrm{S}\left(\mathrm{z}_{\mathrm{i}}\right)$. Аналогічно вершина $z_{i} \in$ попередницею вершини $z_{j}$, якщо вона досягає її вершини. Нехай сукупність вершин-попередниць утворює підмножину $\mathrm{P}\left(\mathrm{z}_{\mathrm{i}}\right)$.

Остаточно перетин підмножин вершин досяжних і вершинпопередниць, тобто підмножина

$$
\mathrm{R}\left(\mathrm{z}_{\mathrm{i}}\right)=\mathrm{S}\left(\mathrm{z}_{\mathrm{i}}\right) \cap \mathrm{P}\left(\mathrm{z}_{\mathrm{i}}\right)
$$

вершини якої не досягаються з будь-якої з вершин множини $z_{1}$, що залишилися, визначає певний рівень ієрархії пріоритетності дії факторів, віднесених до цих вершин. Додатковою умовою при цьому $є$ забезпечення рівності

$$
P\left(z_{i}\right)=R\left(z_{i}\right)
$$

Виконання сукупності вищезазначених дій дає перший рівень (найнижчий з точки зору важливості впливу на досліджуваний процес) ієрархії факторів.
Для визначення його на підставі попередньої матриці будуємо табл. 2.

Другий стовпець табл. 2 номери одиничних елементів відповідних рядків матриці досяжності, третій - номери одиничних елементів стовпців даної матриці.

Рівність (2) виконується для 5-го (ефективність пилота газоочисного устаткування ЕФ) і 6-го (рівень культури виробництва - КВ) елементів (факторів). Згідно з методом аналізу ієрархій [17], ці фактори належать до найнижчого рівня факторів несприятливого впливу на оточуюче середовище. Далі з табл. 2 вилучаємо рядки 5 і 6, а в 1-4 і 7-му рядках - цифри 5 і 6 . Одержимо табл. 3, яка $\epsilon$ основою для обчислення другої ітерації знаходження номерів факторів, що визначають наступний рівень ієрархії.

У другій ітерації рівність (2) виконується для фактора 4, який відображає вплив на оточуюче середовище герметичності устаткування та технологічних установок (ГЕРМ). Цей фактор визначає наступний рівень ієрархії. Відтак з табл. 3 вида-

Таблиця 2

\begin{tabular}{|c|c|c|c|}
\hline $\mathrm{i}$ & $\mathrm{S}\left(\mathrm{z}_{\mathrm{i}}\right)$ & $\mathrm{P}\left(\mathrm{z}_{\mathrm{i}}\right)$ & $\mathrm{S}\left(\mathrm{z}_{\mathrm{i}}\right) \cap \mathrm{P}\left(\mathrm{z}_{\mathrm{i}}\right)$ \\
\hline 1 & 1 & $1,2,3,4,5,6$ & 1 \\
\hline 2 & $1,2,7$ & $2,3,4,5,6$ & 2 \\
\hline 3 & $1,2,3,7$ & $3,4,5,6$ & 3 \\
\hline 4 & $1,2,3,4,7$ & 4,5 & 4 \\
\hline 5 & $1,2,3,4,5,7$ & 5 & 5 \\
\hline 6 & $1,2,3,6,7$ & 6 & 6 \\
\hline 7 & 7 & $2,3,4,5,6,7$ & 7 \\
\hline
\end{tabular}




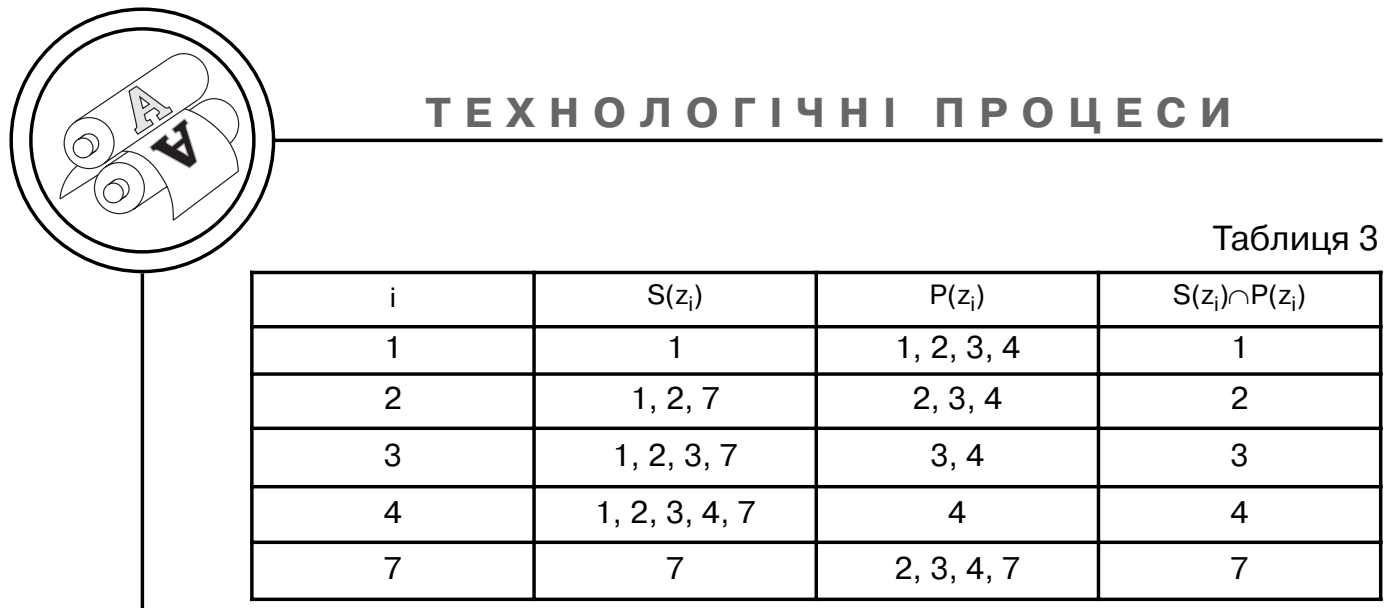

Таблиця 4

\begin{tabular}{|c|c|c|c|}
\hline $\mathrm{i}$ & $\mathrm{S}\left(\mathrm{z}_{\mathrm{i}}\right)$ & $\mathrm{P}\left(\mathrm{z}_{\mathrm{i}}\right)$ & $\mathrm{S}\left(\mathrm{z}_{\mathrm{i}}\right) \cap \mathrm{P}\left(\mathrm{z}_{\mathrm{i}}\right)$ \\
\hline 1 & 1 & $1,2,3$ & 1 \\
\hline 2 & $1,2,7$ & 2,3 & 2 \\
\hline 3 & $1,2,3,7$ & 3 & 3 \\
\hline 7 & 7 & $2,3,7$ & 7 \\
\hline
\end{tabular}

ляємо рядок 4, а в 1-3 і 7-му рядках - цифру 4 й одержимо табл. 4.

Без чергової таблиці зрозуміло, що наступні процедури визначать наступним рівнем ієрархії використовувані матеріали та речовини (МАТ), потім застосовувані технології (ТЕХH), а найвищий рівень в ієрархії займуть вид виробництва (BВ) разом з ступенем впровадження системи охорони навколишнього природного середовища (COHC). Розташувавши фактори за визначеними рівнями, одержимо ієрархічно структуровану модель (рис. 2), що імітує пріоритетність їх несприятливого впливу на оточуюче середовище.

\section{Висновки}

Слід зауважити, що результат віднесення вибраних факторів до відповідного ієрархічного рівня Є об'єктивним процесом, достовірність якого забезпечується використанням відомих засад теорії системного аналізу, теорії моделювання, методології дослідження і розв'язання проблем. Поява конкретного фактора на певному рівні суттєво залежить від встановлених зв'язків між ними, заданих у вихідному графі (див. рис. 1). Ïх зміна за кількістю та суттю зумовить модифікацію одержаної моделі. Якщо кожний з факторів оцінювати деяким числом або присвоювати йому відповідний ваговий коефіцієнт пріоритетності дії факторів несприятливого впливу на оточуюче середовище, то, як випливає 3 рис. 2, важливість факторів відповідає номерові рівня ієрархії. Водночас пріоритетність дії факторів несприятливого впливу на оточуюче середовище $€$ величиною відносною і може бути змінена залежно від екс- 


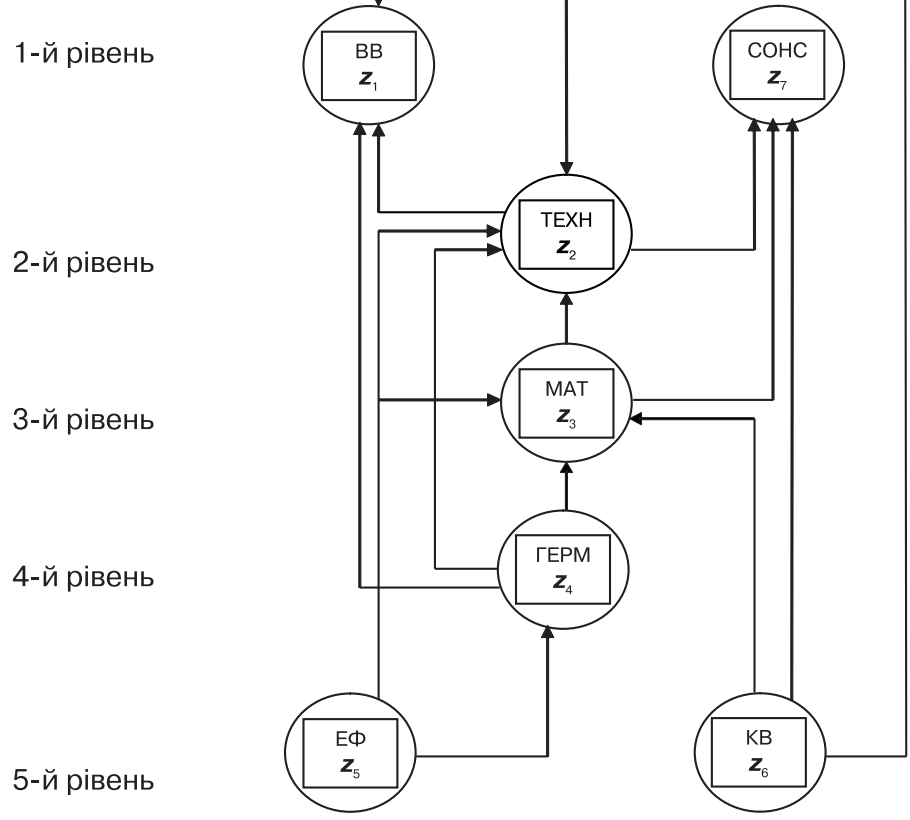

Рис. 2. Модель ієрархії факторів несприятливого впливу на оточуюче середовище

пертної оцінки міри впливу фак- дель, яка визначає рівень дії тора на досліджуваний процес. факторів несприятливого вплиу результаті синтезовано мо- ву на оточуюче середовище.

1. Апостолюк С. О. Охорона навколишнього середовища в деревообробній промисловості : навч. посіб. / С. О. Апостолюк, А. С. Апостолюк, В. С. Джигирей, В. М. Сторожук та ін. - К. : Основа, 2003. - 176 с. 2. Батлук В. А. Высокоэффективное улавливание полидисперсной пыли, образующейся при механической обработке сыпучих материалов и сред / В. А. Батлук, В. К. Батлук, Ю. Е. Шелюх, А. В. Мельников, Р. А. Яцюк // Обработка дисперсных материалов и сред : теория. исследования. технологии. оборудование : междунар. сб. научн. трудов : Вып. 12. - Одесса, 2002. - С. 101-104. 3. Батлук В. А. Дослідження процесу очищення повітря від пилу у пиловловлювачах з додатковою системою очистки / В. А. Батлук, Р. М. Василів, О. В. Мельников // Наукові вісті Ін-тут менеджменту та економіки «Галицька академія» : спец. вип. матеріалів IV Міжнар. наук.-техн. конф. «Еколого-економічні проблеми Карпатського єврорегіону». - 2007. - № 3. - С. 9-15. 4. Батлук В. А. Застосування пиловловлювача з додатковою очисткою для вловлення дрібнодисперсного пилу / В. А. Батлук, Р. М. Василів, О. В. Мельников // Промислова гідравліка і пневматика. - 2007. - № 1(15). - С. 3-6. 5. Батлук В. А. Зменшення кількості викидів дрібнодисперсного пилу від промислових джерел забруднення / 
В. А. Батлук, О. В. Мельников // Наук. вісті (Ін-тут менеджменту та економіки «Галицька академія»). - 2005. - № 1. - С. 142-146. 6. Батлук В. А. Математичне моделювання процесів пиловловлення машин та обладнання / В. А. Батлук, Ю. Г. Кисіль, Р. М. Василів, І. В. Проскуріна, Я. В. Мота, В. Ф. Штанько, О.В.Мельников // Тези доп. VIII Міжнар. конф. «Прогресивна техніка і технологія - 2007», 19-22 червня 2007, Севастополь. - К., 2007. - С. 8. 7. Батлук В. А. Принципово нові напрямки підвищення чистоти повітря для пневматичних агрегатів / В. А. Батлук, О. В. Мельников, Н. В. Ступницька та ін. // Вісник Східноукраїнського нац. ун-ту ім. Володимира Даля. - 2007. - № 3 (109) : Ч. 2. - С. 29-34. 8. Батлук В. А. Процес знешкодження газових викидів при бурінні свердловин / В. А. Батлук, К. І. Азарський, О. В. Мельников та ін. // Зб. тез доп. учасників IV Міжнар. наук.-практ. конф. «Екологія. Людина. Суспільство», 14-16 трав. 2001 р., Київ. - К., 2001. - С. 108-109. 9. Джигирей В. С. Основи екології та охорона навколишнього природного середовища. Екологія та охорона природи : підручн. / В. С. Джигирей, В. М. Сторожук, Р. А. Яцюк. - 3-є вид., доп. Львів : Афіша, 2001. - 272 с. 10. Кузьмінов Б. П. Охорона праці в поліграфічній промисловості. Проблеми гігієни праці та виробничої санітарії : навч. посіб. / Б. П. Кузьмінов, О. В. Мельников. - Львів : Укр. акад. друкарства, 2008. - 127 с. 11. Мельников А. В. Очистка воздуха от пыли при использовании увлажняющих растворов для плоской офсетной печати / А. В. Мельников, В. А. Батлук, Ю. М. Румянцев // Экотехнологии и ресурсосбережение. - 2001. - № 2. - С. 49-52. 12. Сторожук В. М. Особливості отримання дозволу на викиди шкідливих речовин в атмосферу / В. М. Сторожук, О. В. Мельников // Полігр. та вид. справа. - 2010. - Вип. 1 (51). - С. 155-160. 13. Сторожук В. М. Промислова екологія : підручн. / В. М. Сторожук, В. А. Батлук, М. М. Назарук. - Львів : Укр. акад. друкарства, 2006. - 547 с. 14. Закон України «Про дозвільну систему у сфері господарської діяльності» від 06.09.2005 р. № 2806-IV // ВBP. - 2005. № 48. - Ст. 483 (Ост. зміни від 07.07.2010р.). 15. Закон України «Про охорону атмосферного повітря» від від 16.10.1992 р. № 2707-XII // ВВР. 1992. - N 50. - Ст. (Ост. зміни від 03.06.2004 р.). 16. Сеньківський В. М. Модель ієрархії критеріїв якості книжкових видань / В. М. Сеньківський // Наук. зап. (Укр. акад. друкарства).—2007. - Вип. 11. - С. 73-80. 17. Лямец В. И. Системный анализ : вступительный курс / В. И. Лямец, А. Д. Тевяшев. - 2-е изд., перераб. и доп. - Х. : ХНУРЕ, 2004. - 448 с. 